\title{
Information Literacy for the Net Generation to Anticipate the Danger of Intolerance
}

\author{
Heni Nuraeni Zaenudin, Suwatno \\ Faculty of Social Sciences Education, Departemet of Communication Sicences, \\ Universitas Pendidikan Indonesia \\ Jalan Dr. Setiabudhi No. 229 Bandung 40154 \\ Phone. (022) 2013163-2013164 \\ E-mail: heni.nuraeni@upi.edu; suwatno@upi.edu
}

\begin{abstract}
Intolerance behaviors that are not anticipated may give birth to the danger of radicalism both psychologically and physically. This study aims at exploring the way to select and discover informational sources related to the topics; at investigating a means of estimating, accepting, and determining the best thing in the future; at analyzing a means of building new knowledge associated with gained information; and discovering a means of providing and broadcasting information on the website. This study used case study method in order to observe the reality of information literacy and the danger of intolerance among the net generation Observation findings show that the doctrine of intolerance was spread through group discussions of religious Student Activity Unit (UKM). The massive spread of radical viruses is supported by the dominance of the internet as the main medium in information searching. The condition is made worse by low information literacy skills. The results of this study expected to be able to be used as references relating to information literacy for the net generation to anticipate the danger of intolerance which is the forerunner of radicalism. The results showed that the low reading abilities led to a conservative interpretation of religious meanings, which considered one's understanding more correct and accused others as infidels. This phenomenon can be seen from the discovery of limited new knowledge. Hence, the knowledge of information literacy must be introduced in lecture rooms and within intra-university activities.
\end{abstract}

Keywords: Intolerance, Information Literacy, Net Generation

\section{Introduction}

Students are bombarded with various kinds of information. The speed of information through the internet leads to information overload which students should understand about and which highlight the importance of having information literacy skills that include: (1) Choosing and finding information sources that are in line with the topic; (2) Estimating or accepting input from others and determining what is best in the future; (3) Building or creating new knowledge from information obtained; (4) Presenting and disseminating information on website (Abidin, $2018: 88$ ).

Data from the Ministry of Communication and Information revealed the many provocative contents calling on muslims to attack apostates.
The BBC Indonesia website released news on how radicalism and intolerance contents easily found on blogs, sites and social media accounts. The Ministry of Communication and Information stated that negative contents triggered intolerance between religious people. The spread of the dangers of intolerance information is also difficult to anticipate.

Based on observation in UPI's religious Student Activity Unit (UKM), the students like to follow provocative news, which is exacerbated by the low filter ability among them. The internet generation or the net generation is a generation that emerged in the last two decades and have been living with the digital world or computers. Their daily lives cannot be separated from sophisticated 
computer software and are supported by cheaper communication costs making it easier to access information.

The previous studies have analysed the bad impacts of radicalism and intolerancy triggered by media. Hence, accessing and managing media wisely is important. Also, the previous studies which have examined the extremism and violence show that those social realities are easily found in the digital era. The current five-year studies have already analysed the issue on radicalism and violence resulting from new media. However, the anticipacy to handle radicalism -which later leads to radicalism through the informational literacy- has yet to be revealed. Therefore, this study will use the gap as the guideline. This study raises the topic which is the combination of radicalism and terrorism in a developing country.

The internet provides website facilities and social media used as an extension to spread intolerance virus among different religions. The spread of the virus is due to open social media (Kusuma \& Azizah, 2018:10). The increasingly sophisticated communication and information technology has made information reachable from anywhere and anytime. In the book Indonesia's Right Wing Terrorism it is said that Indonesia faced obstacles in carrying out deradicalization on social media (Weimann, 2015:14). (Eisenberg, 2014: 39) Information and technology affects every person in every possible setting - education, public service, and business. Education is fundamentally informationbased. That is, every aspect of learning and teaching requires the gathering, processing, and communication of information. In the past in education, there was a reliance on one primary information resource: the textbook. But this is rapidly changing due in large part to the explosion in information technology and networked information.

Religious intolerance and intolerance to different thoughts often occur within Universitas Pendidikan Indonesia. Intolerance to different ideas can be translated as using religion to attack other people psychologically or physically. Such action is rooted on blunt understanding on religions, in which meanings are drawn rigidly from texts or audiovisuals (Kusuma \& Azizah, 2018: 5). As we know, a meaning is a representation of a point of view. An open thinking will create a moderate attitude which enrich the understanding and interpretation of the information read.

Lack of understanding of good information literacy will bring new problems. The wellknown jargon that the internet is solution to problems applies only to students with ideal reading literacy (Kholisoh, 2018 : 13). Thus, the students are required to have sufficient religious knowledge that can support their good information literacy. Reading literacy typology can develop new understanding and criticize various kinds of information. Students whose information literacy standards are not qualified cannot develop new understanding. Consequently, they are often trapped and get carried away by ideological intolerance.

An observation was conducted on active students at Religious Activity Unit in Universitas Pendidikan Indonesia. Their motivation in joining the unit is to explore information relating to religious knowledge. 
Some respondents are from Islamic Religion Education (PAI) study program and some others from outside the program. Religious information can be obtained from books, newspapers, television, lecturers, tutorials, and the internet. Some steps to sharpen religious knowledge include attending religious studies and having discussion both with peers and lecturers, etc.

It was found that reading resources from new media are still the main prima donna. Three out of eleven respondents stated that finding information in audio and visual formats was more interesting than texts. The other four respondents rarely searched for information from textbooks because the internet has provided various information they need.

The findings suggest that the term online santri was popular among the students because they prefer everything that was instant and of which the final understanding was not based on the steps of reviewing, organizing information and criticism on the discourse. The findings also revealed that students' reading interest was low as when they read, they do not read comprehensively and not deeply rooted. One of the information behaviors identified was the tendency to take the essence of two to three articles they read, which makes it difficult to achieve deep understanding. This leads to conclusion that students' habit of information literacy is still far from ideal.

Students must persevere in looking for different kinds of information and from various media sources. They should keep on practicing higher order thinking skills and how to organize various kinds of information to find accuracy (Kholisoh, 2018: 19). The students with high enthusiasm for reading will possess various information. Their diverse perspective will help them think critically and select each source they receive. This is followed by questioning the information obtained by listening to other people's perspective.

Yusuf Qardhawi (Yaziji \& Doh, 2013: 11) explains that when studying Islamic teaching the typology should consider the similarity of ideas about ideal information literacy. Studying religion requires thoughts based on critical thinking as in the moderate group. Reading various kinds of references is needed in order to compare different schools. The moderate group, which reflects the spirit of the Islamic community as moderate people, is described in the holy Quran. This group regards Islam as a universal religion. Although Islam as religion is naturally transcendental, it has a very high humanitarian orientation.

The previous studies, which have the same issues and use the same conpetual frameworks, are those which are related to technology and radicalism. They have yet to analyse a means of information created and recreated related to the radlicalism ideological goals. In addition, they have yet to discuss the effort to filter information used by the information users (Çoklar, Yaman, \& Yurdakul, 2017: 14). The study with the focus on the issue found in a developing country will be used to carry out propaganda and recruitment of terrorism and radicalism. This study recommends that the regulation of using information through digital media is needed (Behr, Ines von, Reding, Anaiis, Edwards, Charlie, Gribbon, n.d.). It has relation to literacy media and literacy information, the solutions to raise the 
community's awareness of the harm caused by radicalism (Weimann, 2015: 14). Even though this study has discussed wise media selection, it has yet to discover a means of filtering the radicalism information

This research deals with collaborative issues between radicalism and terrorism in developing countries. The issue ws analyzed using literacy and digital communication media cluster. The research problems are formulated as follows: (1) How to choose and find information sources that are in line with the topics; (2) How to asses and accept the input of others and determine what is best in the future; (3) How to build or create a new knowledge out of the information gathered; (4) How is the ability of the net generation in presenting and disseminating knowledge on websites.

On the academic side, this research aimed at providing references relating to information literacy for the net generation in anticipation of the dangers of intolerance, which is the forerunner of radicalism. As for research practice, this research can be used as a consideration on how to improve information literacy skills when exposed to intolerance contents as a result of different understandings of religious teaching.

Thepreviousstudies, usedas thereferences, have explored the fight against radicalism using a website (S.R. Kusumah\&Azizah, 2018:2). This current study investigates information containing new radicalism that are found in new media. The resistance to new radicalism requires the support from all layers starting from the government to community. Ideology Utopia and Islam on Campus : How to Free Speech a Little Information From its Own Terror (Baumann Scoot, 2017:2) shows that the spreading of new ideologies has found in college and / or university environments as a result of the freedom to express opinions. Teror and the Internet We May Be Teaching Information Literacy (Wegener, 2018:2). Wegener states that the information literacy skill is important as this skill will be the foundation of the next-required skill development. Based on the reviews of some previous studies conducted 4 years ago, this study has found that any social issues related to intolerance resulting in radicalism are considerd as a new phenomenon in our society. This study needs to be conduted to complete the findings of the previous studies. During the pre-observation and observation periods, intolerance and radicalism are found in a university environment. A religion Community of the Students at UPI has been selected to be the research object; the reason of this object selection is based on the consideration that the community members have interest in learning Islam in depth. This religion community is related to preaching, tahfidz, tahsin, qiroah, keputrian (Muslimah gathering, usually to share Islamic information), and tilawah.

\section{Method of Research}

This research used case study method as it offers the researchers flexibility to collect a lot of detailed information (Hicks, 2018). Consequently, the researchers can understand the motivation of each respondent specifically as a case. The data was collected in six months from May to November. The data was analyzed by comparing individual's to group's reaction and argumentation obtained 
through interview. The comparison is to find out the literacy ability of each respondent in searching for religious knowledge.

The data collection has been gained through the arranged questionnaires. Next, this study applies an in-dept interview involving the main interview, supporting informants, and experts.

The topic will be analysed using literacy media and digital communication. The participants are a number of college students who were born from 1995 to 2005 who are seen as the active generation using new media to search for information (net generation). This study uses the data triangulation or the combination of varios information related to diverse perspectives. In order to obtain certain knowledge and insight about the occurring phenomena the researchers conducted interviews with experts who had done similar studies. Those experts are the followings: (1) Yunus Abidin, an author of multi literacy book; (2) Ir. Hamli, M.E., Director of the Republic of Indonesia National Counter Terrorism Agency; (3) Dr. Munawar Rahmat, M.Pd.; and (4) Dr. Yakub Malik, M.Pd. The respondents selected were those fell into the category of the net generation and who were active at Religious Student Activity Unit. The names of the respondents are as follows: (1). Dede Selpiyana (2) Bayu Sunarya, (3) Dodi Gustiana, (4) Suryadi (5) Dzilla Mardiah Nurzakiah (6) Fatini Sabrina Azzahra (7) Tina Aprilia (8) Indah Nurmala (9) Ahivi Maghifiroh (10) Zia Nurmala (11) Ika Lestari (12) Tatang Hidayat.
A religion Community of the Students at UPI has been selected to be the research object; the reason of this object selection is based on the consideration that the community members have interest in learning Islam in depth. This religion community is related to preaching, tahfidz, tahsin, qiroah, keputrian (Muslimah gathering, usually to share Islamic information), and tilawah.

\section{Result and Discussion}

\section{Selecting and Finding Information Sources According to Topics}

In today's digital era, information is presented in various forms and obtained from various sources, both printed and electronically. One source of electronic information is the internet, which is also one of the sources used to fulfill various information needs including academic needs. The internet allows information to be obtained quickly, cheaply and diversely, making it an option for a source of information (Hatlevik, Throndsen, Loi, \& Gudmundsdottir, 2018).

Students use information from the internet in completing their academic tasks. Many researches on the topic of their interests are accessible through the search engine. Resource person Fatin Sabrina Azzahra stated that not all information provided on the internet is correct. At first, what is found on the internet will be directly adopted and made as reference. Then, the topic obtained through blogspot or wordpress have to be gradually clarified and checked again. Websites like Sage Pub and Emerald can be the right source of information as there are many quality articles indexed. Students' 
experience of attending media literacy course reinforces how to get information in accordance with topics and needs. The resource person, Fatin, tended to only look information according to needs although some topics appeared without searching.

The participants read detik.com and Pikiran Rakyat digital paper in searching for news. Consuming convergence media allowed them to always be able to find the latest news. Several convergence media publish news two to three times a day and they were able to search for past news posted days ago. Dede Selpiyana stated that for religious news he opted for Media Islam Pilihan, a media portal containing news collection that covers "both sides".

"I have four to five applications of my smartphone. On Media Islam Pilihan, the articles available are, Insha Allah, trusted. For example, the portal covered the news about 212 Peaceful Action and many scholars gave their opinons on the portal (Interview, 4 May 2018).

The Jakarta Post news is very contrasted and gives Islam unfriendly label. Dede gave his analysis based on his observations of several media that had different ideologies. Reading information from media with different ideologies was only limited to knowledge and rarely deeply explored. Searching for different information was aimed at justifying the existing position and contradictory discussions will be avoided in order not to be influenced. It can be inferred that Dede is a conservative and with this type of character, Dede will find it difficult to find new understanding.

In contrast, other respondent named Bayu Sunarya will look for a lot of information that is both in line and the opposite of his perspective. When learning one thing about about religion we will be faced with different point of views. In this case, the respondent used systematic thinking to find new knowledge because what he believes now is not necessarily one hundred percent correct and the one that is contradictory is one hundred percent wrong. His search for the truth is illustrated in the following interview quote.

"Ustad Abu Yazid, the author of Mulya dan Mahaji Salafi, wrote in his book about the prohibition on associating with people who often carry out heresy. He explains that it is forbidden to sit and discuss with people who have different thoughts and commit heresy. Groups that easily blame other people are usually the type of people who are reluctant to be invited to have discussion and do not read many references which make them caught up in old thinking". (Interview, 18 Juli 2018)

Other respondents, Tina and Zia, did not have specific websites to find certain types of information. They were very dependent on Google and used Wikipedia as trusted source for completing academic assignments. Tina had difficulty honing her verbal skills. She was reluctant to ask about the source of information according the topic she wanted to find. Information searching was done randomly. She acknowledged that information obtained from blogspot and wordpress has many similarities but did not have the skills to find out information sources with trusted validity. Both Tia and Zia admitted that they did not take notes and just copy paste the information which was a common practice among students whereas by taking notes of the important information they will be able to find the main ideas of the information, which can be used as sources to explore deeper. 
Almost all conventional information sources, such as dictionaries, encyclopedia, journals, etc are now available in the Net, (Eisenberg, 2014). Librarians. Compared to the internet, books provide more structured references, In books, the explanation will begin with concepts and definitions up to implications on social reality. Students are guided to learn academic language and think systematically. Reference sources and authors are clearly listed so that readers can browse references cited in the book (Çoklar et al., 2017).

In addition to information literacy, digital literacy is needed at the stage of searching for topics as needed. Digital literacy can be defined as the ability to understand and operate digital technologies. Interviews with respondents revealed that the lack of technical skills is the main obstacle in information searching. To achieve the maximum results of searching, the respondents were required to be able to use digital devices properly and understand everything related to digital technology.

\section{How to Assess or Accept Input from Other People and Determine the Best Knowledge in the Future}

When attending a lecture, one of student's main roles is listening for information. In listening activities more information is obtained than talking. Lecture rooms and religious Student Activity Units are places where discussion often occurs among students. Active listening skills involve the process of active understanding to obtain information. It entails cognitive process to produce messages from the speaker. Besides listening, participation also becomes part of the process of receiving input from others. Participation is described as giving questions to speaker to clarify and confirm (Abidin, 2018).

Discussion is one of the activities to find information in order to solve problems. The resource person received input regarding the issue and makes it the focus of attention. The third parties will provide various alternative opinions. Once collected, the resource person will analyze various information from textbooks, group discussion or discourses through social media and websites. Discussion groups consist of small number of people of which the members are those who have same interests and the same goal to find new understanding (Scott-Baumann, 2017).

Involved in UKDM Student Activity Unit, Fatin aimed to study religion in stages. UKDM has a structured curriculum in fostering its members and cadreization is carried in stages as well from basic to advanced knowledge. For the initial cadreization stage, UKDM teaches its members aqeedah, fiqh and muamalah. Members are encouraged to read fiqh books from the first to the fifth edition. Fatin did not find any difficulties during cadreization because she attended Islamic boarding school since junior high school. She combined knowledge from textbooks with that from primary data. As an extroverted student, she found sharing opinion activities fun.

Discussion and collaboration skills are intended to equip students to be able to communicate. Students who like 
interactions tend to explore information both in written and oral. They must posses speaking and listening skills and be able to collaborate with others to create interaction. In communication science, listening with empathy is one of the keys to a more effective two-way communication.

During group discussion, participants need to equate perceptions. The problem of radicalism, terrorism, liberalism, and secularism is sometimes ambiguous with many meanings, which leads to contradictory objectives. Students with critical thinking look for contradictory thoughts to gain new knowledge. Narrative resistance is not something taboo but a natural thing.

An expert from Islamic Education Study Program, Dr. Munawar Rahmat, argues in an interview that students must be honed with argumentation skills, which can not be separated from the ability of reasoning and logic. The philosophy of science course will help students in describing the truth through premises. It works simply by analyzing a series of premises based on which information can be trusted and which can not. Out of numerous debates about muamalah with non-muslims, the best thing to make as a reference is to respect and giv examples of the noble truth.

One respondent had an experience following an Islamic study group that misled aqeedah. The gathering was found through social media links in search for the truth. The materials delivered provides propaganda via the internet and directly criticize the doctrine about oneness of God. Discussion on tawheed requires intelligent reasoning and logic. The speaker of the study group gave a statement that was not in line with what the respondent has learned in school religious activities and thus the respondent looked for a second opinion from a religious teacher in campus and learned that the teaching of monotheism is an absolute belief.

A personal development group is needed by the students to find balance when bombarded with Marxism, secularism and socialism. Interacting with pluralism belief has made the students into characters who always look for a midpoint. The face-to-face group is basically for support in which it is possible for each member to express his thoughts about fear and to suppress anger.

One respondent, Dede, joined 212 action with the conviction that every muslim has an obligation to choose leaders from the Muslim group. Electronic newspaper republika.com, detik.com, several Islamic websites, radio stations, streaming TVs, da'wah videos and scholars' social media are examined as sources of information. A verse in the Quran, Surah Ali-Imran 28, is the reinforcer of his belief. There are several verses in the Quran that are already clear and final and one of them is about the prohibition of taking infidels as leaders. The peaceful action attended by the respondent was a form of practicing democracy and it is the right of every Indonesian citizen to voice their opinion, which is also protected by the 1945 Constitution.

The desire to preach on Islamic sharia began to be realized. Looking for new knowledge from lecturers and colleagues was done to deepen his belief. It was not 
uncommon for the student to find colleagues who had contrastive understandings. The differences were accepted but when it came to Islamic teachings that were absolute, the student would try to defend his belief. Interacting with the non-muslims was acceptable but not by compromising ideology.

\section{Building or Creating New Knowledge from the Information Obtained}

Community members such as lecturers, students and researchers need more information to satisfy their needs. The information obtained will be used as knowledge to solve life problems. Gap between hope and reality will emerge when searching for solution. Thus, strategies are needed to make knowledge from the information gathered.

The respondents should ideally observe by using old knowledge to find new one. Observation is an investigation that is continuously organized to find knowledge. It must go through the critical stages of information. Respondent Bayu, Dodi, Ika, Suryadi and Fatin conducted observation with the following information literacy stages: (1) Identifying information needs; (2) Selecting and determining appropriate information sources; (3) Choosing relevant information; (4) Organizing and compiling information; (5) Comparing, criticizing and evaluating information sources; (6) Accepting input from others for the best in the future (Çoklar et al., 2017). These stages are known from attending courses or self learning.

Fatin's willingness to attend UKDM
Student Activity Unit was because whe wanted to deepen his religious knowledge to preach, which was done by following the da'wah of several preachers. After all the relevant issues were organized and compared with one another, he finally came with an answer. She concluded that when inviting others to virtue, it is important to straighten out intentions. She could also distinguish between dealing with small and large congregation. She learned that running a missionary activity in groups is more effective. Each individual will strengthen each other and conduct joint evaluations, including when she found Islamic extremist content and tried to seek clarification to find an ideal concept of da'wah.

Initiation skills are useful for students to motivate them in carrying out their beliefs. Social interaction skills in facing a variety of social groups are the necessary provision to work in different groups, which eventually enable them to deal with a plurality of understandings. This involves the ability to process suggestions received and think positively about criticism. Open thinking is needed because each individual has a different perspective.

Dodi's research for new knowledge was not easy because he never studied at Islamic boarding school nor consistently following Islamic religious study community. That research for religious knowledge was dominated by textbook reading and online group discussion. His interest in the concept of enforcing Islamic sharia brought him to a variety of relevant sources from which he found answers to his questions. There are 
also many textbooks and online sources that gave radical labeling. The authorities have concerns if a developing ideology defeats the existing ideology believed by the state. The respondent concluded that the West took part in practicing hegemony in in many developing countries.

The respondent strongly agreed with the steps taken by Hizbut Tahrir Indonesia (HTI) to try to uphold an Islamic state by leaving the government system. Dodi argues that with Islamic party such as PKS it will be difficult to apply the sharia law if still take shelter in a secular system. He compared the information obtained and concluded that the way of preaching conducted by the Prophet Muhammad when he refused to enter the Quraish government system and chose to migrate This step is effective because there should be no comprise in trying to make changes to the system. The correspondence theory holds that a statement is true if it corresponds to the fact of truth or something is true if there is correspondence (Abidin, 2018).

Anotherrespondent, Bayu, wasinterested in the issue discussed in a magazine entitled War of Terrorism. He argues that western media have a double standard in covering terrorism issue. Intolerance and violence has also been carried out by the US government in several muslim countries. Radicalism and terrorism are also committed by Israel. New knowledge was gained from discourses on several websites and one of the most quoted is INSIST website. The reasons for choosing INSIST is because its Islamic scholars had educational background that could not be underestimated. Some scholars studied Islam in the Middle East such as Egypt. The arguments are always delivered with logical reasons and used academic approaches. Islamic views that are too theoretical in the classroom have been developed into practice through several websites and online media.

The respondents gained an understanding from the discourse they read on the media. A new understanding is born if the respondent is consistent in studying the knowledge. Some knowledge can finally answer the questions of what, why and how. Sometimes truth can be proven speculatively. In contrast to natural science, the objectivity of social science is derived from the experience of an individual such as the definition of intolerance, radicalism, right radicalism, extremism, thogut, Islamic state, khilafah, etc. The respondent tried to to compare some information from different sources and counter information will be organized to find a new understanding.

Discussion is one of the activities to collaborate one view with another. The respondent believed that truth could also be obtained through language. Thoughts channeled through language gave birth to a number of creative ideas that may be speculative although those ideas should be rethought deeply. This mindset is known as radical, comprehensive, and coherent thinking.

\section{The Ability to Present Knowledge and Spread It through the Website}

All forms of information can be communicated through spoken language, newspaper, videos, etc. In the phrase "the 
ordinary notion of information" (quoted from Fox), notion can be delivered through human languages. Written language is one of the civilizations created by humans. Through writing, humans can transform legacies from time to time (Çoklar et al., 2017). New knowledge related to religious education obtained by Tatang, one of the respondents, was collected from journals. Online media was selected in order to get the most up-todate knowledge from the journals. Based on his experience, data from journals is more accurate than that of books. This claim can be held accountable from subjectivity. Data search through journals was conducted to complete campus assignments.

The enthusiasm for exchanging knowledge has been done since fifth semester. Light articles were written on personal media or mass media. Ideas can be developed through writing which is considered quite effective for da'wah purpose. To deepen the coverage, he used various methods including gathering information, choosing issues, recording important ideas, and pour ideas into writing.

The respondent tried to grasp the concepts before writing by reading, researching, having dialogues and conducting interview with experts. Relevance was obtained by browsing several titles in order to promote the honesty of academics. Following national forums that raises Islamic education is considered important to find out various opinions from different perspectives. Discussion with various community organizations is useful to compare and foster critical attitude. Discussion and collaboration indirectly motivate the respondent to write in depth.

Collaboration through discussion across different religious community organizations is important to do. During his activism at Religious Student Activity Unit, he conducted gathering with student association forum and student executive body (BEM). Outside the campus environment, the discussion was carried out with clerics in the neighborhood and sub-districs around the campus. The gathering aimed to open the barrier between the community and the students. The community's anxiety about the dangers of promiscuity, drugs and radicalism were used as references to find solutions to the problems. The respondent realized that students as agents of change must contribute their thoughts and actions to help the community solve existing problems.

When doing collaboration aimed at generating new knowledge, the respondent found contradiction on the notion of radicalism. From information searching, the respondent concluded that the word radicalism originated from radical meaning rooted. If it is associated with the spirit of studying religion, a radical attitude is then needed. However, there has been a shift in its meaning in the present era, which is associated with the behavior of interpreting religion rigidly.

The final stage is the stage of processing all information obtained in one writing. At this stage, the respondent used his knowledge, language and writing style to create an article with different style that is adjusted to the segmentation of the reader. The respondent took part in an article writing 
training to sharpen his writing. His practical experience taught him that an idea can be packaged according to its purpose. His articles have been published in mass media such as Republika newspaper, kumparan. com and tirto.id.

\section{Conclusion}

Lack of credible sources is associated with the lack of the students' literacy. As a result, they are struggling with the needed information identification. The informants tend to select information merely from one source which leads them to possess poor resistance to the misleading religios ideology. The informations whose good information literacy skills will say that the school of salafi is no longer relevant to the society development today. Based the data analysis, a discussion is an ideal way to search for credible information.

After the respondents discovered new religious knowledge, those with conservative personalities were reluctant to find a second opinion to discuss. In fact, expert such as Dr. Munawar Rahmat states that the students should hone their argumentation skills which are derived from reasoning and logical abilities

\section{References}

Abidin, Y.(2018). Pembelajaran Multiliterasi. Bandung: PT. Refika Aditama.

Behr, Ines von, Reding, Anaïs, Edwards, Charlie, Gribbon,L.(n.d.).Radicalisation in the digital era The use of the internet in 15 cases of terrorism and extremism. Cambridge.

Çoklar, A. N., Yaman, N. D., \& Yurdakul, I. K. (2017). Information literacy and digital nativity as determinants of online information search strategies. Computers in Human Behavior, 70, 1-9. https://doi. org/10.1016/j.chb.2016.12.050

Eisenberg, M. B. (2014). Information Literacy: Essential Skills for the Information Age. DESIDOC Journal of Library \& Information Technology, 28(2), 39-47. https://doi.org/10.14429/djlit.28.2.166

Hatlevik, O. E., Throndsen, I., Loi, M., \& Gudmundsdottir, G. B. (2018). Students' ICT self-efficacy and computer and information literacy: Determinants and relationships. Computers and Education, 118(November 2017), 107-119. https:// doi.org/10.1016/j.compedu.2017.11.011

Hicks, A. (2018). Making the Case for a Sociocultural Perspective on Information Literacy. In The Politics of Theory and the Practice of Critical Librarianship (pp. 69-85). Sacramento: Library Juice Press.

Kholisoh, N. (2018). Pengaruh Terpaan Informasi Vlog di Media terhadap Sikap Guru dan Dampaknya terhadap Persepsi Siswa. Jurnal ASPIKOM, 3(5), 1002. https://doi.org/10.24329/aspikom. v3i5.380

Kusuma, R. S., \& Azizah, N. (2018). Melawan Radikalisme melalui Website. Jurnal ASPIKOM, 3(5), 943. https://doi. org/10.24329/aspikom.v3i5.267

Scott-Baumann, A. (2017). Ideology, utopia and Islam on campus: How to free speech a little from its own terrors. Education, Citizenship and Social Justice, 12(2), 159-176. https://doi. org/10.1177/1746197917694183

Weimann, G. (2015). Terror and the Internet. International Encyclopedia of the Social \& Behavioral Sciences: Second Edition (Second Edi, Vol. 24). Elsevier. https://doi.org/10.1016/ 
B978-0-08-097086-8.95091-8

Yaziji, M., \& Doh, J. P. (2013). The Role of Ideological Radicalism and Resource Homogeneity in Social
Movement Organization Campaigns against Corporations. Organization Studies, 34(5-6), 755-780. https://doi. org/10.1177/0170840613479235 